\title{
Epidemiology of Megninia spp. in laying flocks from the State of Minas Gerais, Brazil
}

\author{
Epidemiologia de Megninia spp. em estabelecimentos de postura no Estado de Minas Gerais, Brasil \\ Leandro do Carmo Rezende ${ }^{1}$; Lucas Maciel Cunha ${ }^{1 *}$; Nelson Rodrigo da Silva Martins ${ }^{1}$; \\ Cristina Mara Teixeira ${ }^{1}$; Paulo Roberto de Oliveira ${ }^{1}$
}

\begin{abstract}
${ }^{1}$ Departamento de Medicina Veterinária Preventiva, Escola de Veterinária, Universidade Federal de Minas Gerais - UFMG, Belo Horizonte, MG, Brazil
\end{abstract}

Received February 4, 2015

Accepted February 5, 2015

\begin{abstract}
Aspects related to the epidemiology of Megninia ginglymura were studied, in order to determine predisposing factors for the ocurrence in layer chicken houses of commercial farms in the State of Minas Gerais, Brazil. An observational, cross-sectional, analytical survey was conducted for identifying major risks or protection factors for infestations. Four hundred thirty-one houses located in forty-three farms were visited in 2012. Regarding the farms, 17 (39.53\%) had chickens infested by $M$. ginglymura and $1(2.32 \%)$ presented Megninia cubitalis. The epidemiological aspects of the occurrence of $M$. ginglymura were investigated using multiple logistic regression models. The chicken house organization was an important protection factor involved in the occurrence of $M$. ginglymura (odds ratio $[\mathrm{OR}]=0.85$ ). The presence of subsistence breedings of poultry within the premises or at the proximity of a farm was characterized as a risk factor for the occurrence of infestations $(\mathrm{OR}=3.92)$. The use of mineral oil $(\mathrm{OR}=0.16)$ was considered protective against new infestations. Some regions of the state were characterized by a higher risk for mite infestation than others.
\end{abstract}

Keywords: Acari, Analgidae, feather mites, Megninia ginglymura, Megninia cubitalis.

\section{Resumo}

Aspectos relacionados à epidemiologia de infestaçóes pelo ácaro Megninia ginglymura foram estudados com o objetivo de determinar os principais fatores para a ocorrência desse ectoparasito em galinhas poedeiras de granjas comerciais no Estado de Minas Gerais, Brasil. Um estudo observacional, analítico e seccional foi realizado para verificar os principais fatores de risco ou proteção para as infestações. Quatrocentos e trinta e um galpóes distribuídos em quarenta e três granjas foram visitados, no ano de 2012. Em relação às granjas, 17 (39,53\%) possuíam aves infestadas por M. ginglymura e uma $(2,32 \%)$ apresentou galinhas infestadas por Megninia cubitalis. Os aspectos epidemiológicos para a ocorrência de $M$. ginglymura foram investigados, utilizando-se modelos de regressão logística múltipla. A organização dos galpões nas granjas foi verificada como um importante fator de proteção envolvido na epidemiologia dessa espécie (Razão de Chances $=0,85)$. A presença de criaçóes de galinhas de subsistência dentro das instalaçóes das granjas ou nas proximidades (Razão de Chances $=3,92$ ) foi caracterizada como um fator de risco para a ocorrência de infestaçóes. O uso de óleo mineral foi considerado um fator de proteção contra infestaçôes por M. ginglymura. Algumas regiôes do Estado de Minas Gerais foram caracterizadas como de maior risco do que outras para infestaçóes por esse ácaro.

Palavras-chave: Acari, Analgidae, ácaros plumícolas, Megninia ginglymura, Megninia cubitalis.

\section{Introduction}

Some species of arthropods of the subclass Acari are important ectoparasites of birds (PROCTOR, 2003). The major feather mites of domestic chickens belong to the family Analgidae, especially to the genus Megninia (Acari: Analgidae). The main morphological

${ }^{*}$ Corresponding author: Lucas Maciel Cunha. Departamento de Medicina Veterinária Preventiva, Escola de Veterinária, Universidade Federal de Minas Gerais - UFMG, Campus Pampulha, Av. Antônio Carlos, 6627, CP 567, CEP 31270-901, Belo Horizonte, MG, Brasil.

e-mail: lucasmcunha82@gmail.com characteristic of this genus is the presence of a handle-shaped elevation on the proximal segment of legs (GAUD et al., 1985). Megninia ginglymura (Mégnin, 1877) and Megninia cubitalis (Mégnin, 1877) are the most common species of this genus described in chickens in Brazil. The morphological differences between these species are based on the observation of epimera and adanal setae. M. cubitalis has Y-shaped epimera, while M. ginglymura shows unfused epimera. The adanal setae of M. cubitalis are aculeiform, 
while in $M$. ginglymura they are inflated and relatively bigger (AMARAL et al., 1975; TUCCI et al., 2005).

Mites of the genus Megninia live on the host, laying their eggs on the feathers (HERNÁNDEZ et al., 2007). Adults and juveniles live and feed on the feathers. Mites are grouped into body parts such as head, chest, back and wings. Mite-infested feather barbules become rarefied and the follicles become swollen and erythematous (REIS, 1939).

In an outbreak in a laying poultry farm in the State of São Paulo a reduction in egg laying of around $20 \%$ and the appearance of itchy lesions caused by the mite saliva were observed. Furthermore, it was verified that the serous fluid released dries to form crusts, providing the opportunity to secondary bacterial infection, which may cause pyoderma. A fungal contamination of lesions may also occur (TUCCI et al., 2005).

Recently, the mite Allopsoroptoides galli (Psoroptoididae: Pandalurinae) was described in laying hens in Brazil (MIRONOV, 2013). The hens parasitized by $A$. galli show intense itching, desquamation and a marked drop in egg production (approximately 30\%) (TUCCI et al., 2014). The blood profile is negatively affected, and biochemical changes are also observed in infected hens (BUIM et al., 2013). Although little studied, the occurrence of feather mite infestations in commercial laying hens is a subject of extreme health and economic relevance to veterinary medicine. Further research is necessary in order to develop better strategies for prevention and control of these ectoparasites.

Most reports of $M$. ginglymura in Brazil have described its occurrence in subsistence poultry, and little or no attention has been dedicated to commercial poultry flocks (TUCCI et al., 2005; REZENDE et al., 2013). Therefore, this study aimed at investigating the occurrence and main epidemiological aspects of infestations in chickens of commercial layer flocks in the State of Minas Gerais, Brazil. Each flock was analyzed for the presence or absence of $M$. ginglymura in poultry, but their quantification was outside the scope of this study. The epidemiological aspects of $M$. cubitalis were not analyzed due to the low frequency of occurrence.

\section{Materials and Methods}

\section{Geographic area}

The study was conducted in commercial laying chicken farms in the State of Minas Gerais, Brazil. This state, located in the southeastern region of Brazil, has an area of $586,522.122 \mathrm{~km}^{2}$ and is characterized by large range of climatic conditions. Regions in the north of the state have higher temperatures than those located in the south. Most of the regions have a high-altitude tropical climate (GARCIA et al., 2007).

During the period of visits to the farms, the temperature ( 12.4 to $\left.39.1{ }^{\circ} \mathrm{C}\right)$ and relative humidity $(\geq 30 \%)$ were monitored in cities where the farms were located. This monitoring was done in order to determine whether climatic variations could affect the presence or absence of ectoparasites in flocks. Farms located in cities with temperatures below $5^{\circ} \mathrm{C}$ or above $40{ }^{\circ} \mathrm{C}$ were not visited.

\section{Sampling}

The implementation of a national plan for poultry health in Brazil has resulted in compulsory periodic inspection and geo-referencing of commercial poultry flocks. Small-scale poultry housing for family consumption only are referred to as subsistence breedings and are not covered by the national plan. The geo-referencing data of Agricultural Institute of Minas Gerais (IMA) were used for determining the number of farms to be sampled in each region of the State (Figure 1).

The random selection of farms and stratification of the samples was performed considering the proportion of industrial laying poultry farms in each of the 20 IMA administrative regions of the state. Thus, from March to July 2012, 431 chicken houses were visited in 43 farms. The number of houses per farm ranged from 1 to 40 and the average number was 10 (Standard Deviation= 5.49). Forty-one farms kept poultry in cage systems and 29 were intended to breeding replacement pullets.

The individual examination of 20 chickens per house and poultry facility inspection for ectoparasites and other arthropods were performed, with mite and feather samples collected. Samples were packed in airtight plastic bags, transported refrigerated to the laboratory and stored at $-20 \pm 2{ }^{\circ} \mathrm{C}$ until processing.

Mite specimens were prepared in Hoyer's medium (KRANTZ, 1978) and mounted between glass slides and coverslips. Morphological characteristics were determined using an optical microscope (Olympus, Japan). Species of genus Megninia were identified as described previously (GAUD et al., 1985; TUCCI et al., 2005). Differential diagnosis of the feather mite Allopsoroptoides galli (Acari: Psoroptoididae), which was recently described in chickens of commercial farms in Brazil (MIRONOV, 2013), was performed.

\section{Questionnaire}

During visits to the poultry establishments, an adapted questionnaire was applied in order to obtain information related to predisposing factors for the occurrence of ectoparasites (CUNHA, 2013). A preliminary version of the questionnaire, containing a total of 97 possible answers to objective and categorical questions, was prepared and submitted to a test-retest validation procedure, using kappa coefficient. Questions with reliabilities ranging from regular to excellent ( $k a p p a$ greater than $0.4, \mathrm{p} \leq 0.05$ ) or with unanimous answers were kept (LANDIS \& KOCH, 1977). The final version of the questionnaire contained a total of 89 possible answers. This study was approved by the ethics committees of the Federal University of Minas Gerais - UFMG (COEP/UFMG Ethic Number 0238.0.203.000-11 and CETEA/UFMG 41/2011).

\section{Statistical analysis}

The simultaneous evaluation of different risk factors for the occurrence of infestations by $M$. ginglymura was performed using logistic regression models, as described by Dohoo et al. (2003). These models were constructed using software Stata ${ }^{\circledR} 12.0$ and considered the chicken house as the unit of statistical analysis (HOSMER \& LEMESHOW, 2000). The farms were used as conglomerate of active poultry houses for sample size calculation considering a hypothetical prevalence of $50 \%$, a standard error of 


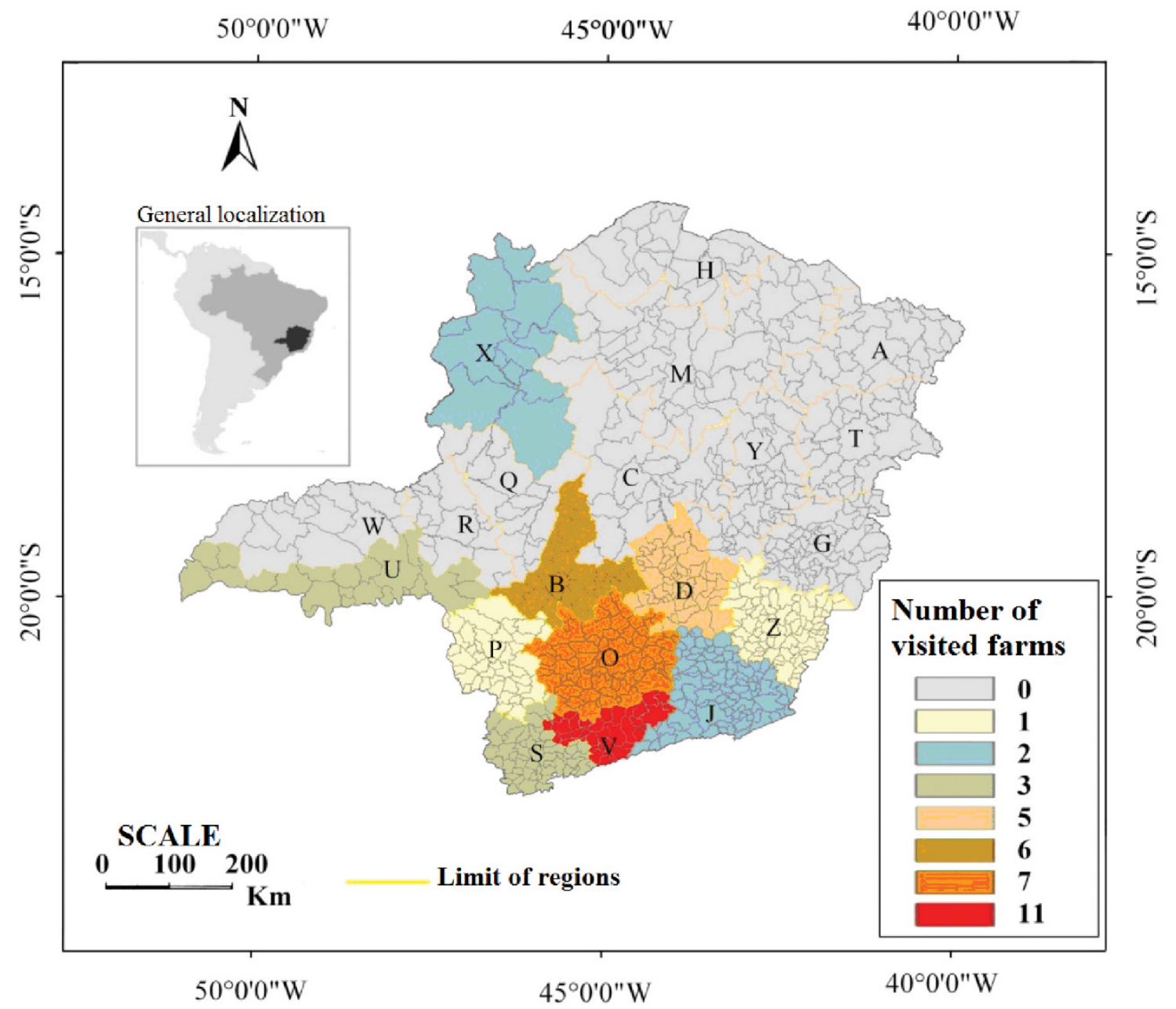

Figure 1. Map with the number of farms visited in regions according the Agricultural Institute of Minas Gerais (IMA), Minas Gerais, Brasil, 2012. A- Almenara; B- Bambuí; C- Curvelo; D- Belo Horizonte; G- Governador Valadares; H- Janaúba; J- Juiz de Fora; M- Montes Claros; O- Oliveira; P- Passos; Q- Patos de Minas; R- Patrocínio; S- Pouso Alegre; T- Teófilo Otoni; U- Uberaba; V- Varginha; W- Uberlândia; XUnaí; Z- Viçosa.

$5 \%$ and a finite number of farms. The quantification of the intensity of infestation in houses or on the hosts was not performed. Thus, only the verification of the presence or absence of $M$. ginglymura was performed in each house.

The preliminary selection of variables to be included in the logistic models was performed using the chi-square test, Fisher's exact test and univariate logistic regression, removing the variables with p-value less than 15\% (DOHOO et al., 2003). Variables selected by univariate statistical tests were used in multivariate logistic regression models, except for confounding or not significant ( $p \leq 0.05)$. The characteristics with suspect hierarchical or clustering relation effect had the values of intra-class correlation (ICC) calculated. Variables with high values $(\geq 0.40)$ were transformed in dummy variables. The analysis of odds ratios (OR) ( $95 \%$ significance) was also used for variable selection and construction of the models. Variables with significant OR $(p \leq 0.05)$ or variables in which removal would disrupt the general model were kept. The verification of model fitness was performed using the Wald's test $(p \leq 0.05)$ and the Hosmer-Lemeshow test $(\mathrm{p}>0.05)$. The area under the receiver operating characteristic (ROC) curve and the value of the pseudo-coefficient of determination were also considered for choosing the logistic model (HOSMER \& LEMESHOW, 2000).

\section{Results}

Eighteen (41.86\%) farms and seventy-eight chicken houses $(18.09 \%)$ showed infestations by mite of the genus Megninia. M. ginglymura was the most frequent species, being found in seventeen $(39.53 \%)$ farms and in seventy-six houses $(17.63 \%)$. M. cubitalis was found in one (2.32\%) farm and in two houses $(0.46 \%)$.

Table 1 presents the selected screening characteristics using the chi-square and Fisher's exact tests, and univariate logistic regression. The farm's geographic region, considered a priori a variable associated hierarchically with the occurrence of $M$. ginglymura, presented an ICC value of 60.56 . Thus, this variable was decomposed (by creating dummy variables) to evaluate the regions separately. Chicken house organization within the farm was a significant factor in preliminary hierarchical logistic models ( $p>0.001$ ). Thus, this variable was allocated to a general logistic model. The 
Table 1. Characteristics potentially associated with the occurrence of infestations by Megninia ginglymura selected by univariate statistical tests $(\mathrm{p}<0.15)$.

\begin{tabular}{|c|c|}
\hline Characteristic & p-value \\
\hline Region* & 0.000 \\
\hline Farm\# & 0.008 \\
\hline Chicken house organization* & 0.024 \\
\hline Type of facilities* & 0.055 \\
\hline Predominant chicken genetic lineage* & 0.000 \\
\hline Number of chickens by cage* & 0.095 \\
\hline Number of chickens by square meter* & 0.095 \\
\hline Presence of rodents* & 0.002 \\
\hline Presence of mice (Mus musculus)* & 0.000 \\
\hline Presence of feral pigeons (Columba livia)* & 0.000 \\
\hline Presence of subsistence chickens* & 0.109 \\
\hline Presence of ruddy ground dove (Columbina sp.) ${ }^{*}$ & 0.000 \\
\hline Presence of cattle egret (Bubulcus ibis)* & 0.102 \\
\hline Presence of chopi blackbirds (Gnorimopsar chopi)* & 0.038 \\
\hline Presence of saffron finchs (Sicalis flaveola)* & 0.016 \\
\hline Presence of other synanthropic birds* & 0.000 \\
\hline Use of acaricides* & 0.000 \\
\hline Biological control* & 0.052 \\
\hline Use of mineral oil to control mites* & 0.000 \\
\hline Use of silica to control mites* & 0.000 \\
\hline
\end{tabular}

* Pearson's Chi Square test/ Fisher's Exact Test. \# Univariate Logistic regression.
Table 2. Characteristics associated with the occurrence of Megninia ginglymura in commercial laying poultry flocks in the State of Minas Gerais, Brazil (2012).

\begin{tabular}{|c|c|c|c|c|}
\hline \multirow{2}{*}{$\begin{array}{l}\text { Characteristic } \\
\text { Chicken house } \\
\text { organization }\end{array}$} & \multirow{2}{*}{$\begin{array}{r}\text { Odds } \\
\text { ratio }\end{array}$} & \multicolumn{2}{|c|}{$\begin{array}{c}\text { Confidence interval } \\
(95 \%)\end{array}$} & \multirow{2}{*}{$\frac{\text { p-value }}{0.000}$} \\
\hline & & 0.78 & 0.92 & \\
\hline $\begin{array}{l}\text { Presence of } \\
\text { subsistence chickens }\end{array}$ & 3.92 & 1.20 & 12.75 & 0.023 \\
\hline Use of mineral oil & 0.16 & 0.036 & 0.71 & 0.016 \\
\hline $\begin{array}{l}\text { Region of Belo } \\
\text { Horizonte }\end{array}$ & 40.19 & 4.29 & 376.28 & 0.001 \\
\hline $\begin{array}{l}\text { Region of Juiz de } \\
\text { Fora }\end{array}$ & 10.55 & 0.49 & 223.09 & 0.130 \\
\hline Region of Oliveira & 21.12 & 2.22 & 200.20 & 0.08 \\
\hline $\begin{array}{l}\text { Region of Pouso } \\
\text { Alegre }\end{array}$ & 60.46 & 6.17 & 591.67 & 0.000 \\
\hline Region of Varginha & 14.02 & 1.64 & 119.76 & 0.016 \\
\hline Region of Viçosa & 1259.87 & 44.99 & 35280.43 & 0.000 \\
\hline
\end{tabular}

Number of valid observations: 374 ; reference region for calculating odds ratios: Bambuí; $p$ value for goodness of fit of the model in the Wald test: $<0.001$; $p$ value for goodness of fit of the model in the Hosmer-Lemeshow's test: 0.5129; model sensivity (probability + infested): $27.63 \%$; model specificity (probability - noninfested): $94.30 \%$; area under the curve of the receiver operating characteristics (ROC): $83.94 \%$.

\section{Discussion}

The vast majority of studies in Brazil characterize Megninia spp. as a parasite of little importance for the poultry industry due to low frequency of occurrence (REZENDE et al., 2013). However, the occurrence of such genus of mites, mainly $M$. ginglymura, was observed in $18.09 \%$ of commercial flocks studied, indicating relevant frequency. Mixed infestations of $M$. ginglymura and M. cubitalis were not observed in this study. These results are in disagreement to those of Tucci et al. (2005), who described mixed infestations by $M$. cubitalis and $M$. ginglymura in a farm in the State of Sáo Paulo, Brazil. In other countries, the occurrence of these parasites in poultry varies, ranging from $2.6 \%$ in Israel (MUMCUOGLU \& LUTSKY, 1990) to $89.6 \%$ in Cuba (HERNÁNDEZ et al., 2006).

The presence of synanthropic birds in nearby of houses was evaluated in order to assess the role as mechanical carriers of ectoparasites. Although the presence of avian species such as cattle egret and saffron finch did not appear as significant factors in preliminary models, the presences of ruddy ground dove, feral pigeons and other synanthropic birds were significant factors and showed OR lower than 1 . The results suggest that there is a relationship between the presence of populations of $M$. ginglymura and the absence of birds in sheds. These results might result from the interference of confounding variables such as stricter biosecurity measures that were not approached in the study and that would reduce the presence of synanthropic birds in the farms.

The use of wire mesh fences to prevent the entry of birds in chicken houses was not associated with the absence of these mites in univariate statistical analysis. Wire mesh fencing was not 
primarily added for contention of synanthropic birds, but was mainly used for containment of replacement pullets (pre-adult layers) in non-cage floor raised systems and for preventing the entry of other animals such as predators.

No association was observed between the use of acaricides and the occurrence of infestations by $M$. ginglymura. These results are possibly due to fact that these pesticides are used on the control of other species of mites. Thus, these products may have low efficacy to reduce infestations by $M$. ginglymura to undetectable levels.

In the logistic regression model for $M$. ginglymura, the spatial variable order of chicken house in farm was significant. The houses are usually numbered sequentially in increasing order in farms and those with lower numbers are located closer to the periphery or at the farm gatehouse. The results demonstrated that houses with higher order numbers have chances 1.17 times smaller to be infested by $M$. ginglymura. Probably, houses closest of the edges and entry of the farms, which have a lower order numbering, are more likely to be infested. The removed or centralized chicken houses, due the lower contact with the boundaries of farm, have less interaction with sources of contamination such as synathropic hosts, avian with mechanic carrier function and fomites.

The presence of subsistence breedings of chickens at proximity increased the chances of infestations almost four times (Table 2). The proximity is determined when the subsistence chickens can keep contact with commercial poultry or when these breedings were kept inside or in neighborhood of commercial houses. These poultry are not of industrial lineages and are breeding for self-consumption at the farm and nearby. As generally known, the inexistence of health, preventive medicine and nutritional control in these chickens will favor the occurrence of parasitism and other diseases.

The use of mineral oil against ectoparasites was significant in logistic model and showed an OR lower than one. In sheds in which mineral oil was used, chances of infestations were approximately six times smaller. The use of mineral oil to combat insects, mites and other agricultural pests has been reported in the literature, including against hematophagous mites (GUIMARÃES \& TUCCI, 1992). There is other reports of use of mineral oil against invertebrates such as Dermanyssus gallinae (Acari: Dermanyssidae) kept under laboratory conditions (MAURER et al., 2009). In the case of D. gallinae, there was a reduction of mite reproduction when mineral oil was used as control action (MAURER et al., 2009). Thus, hematophagous mite control would probably also reduce $M$. ginglymura population, due to inadequate reproduction conditions (GUIMARÁES \& TUCCI, 1992).

The variable region had a high ICC value, which showed that there is a spatial distribution in the chances of occurrence of infestations. Thus, in order to evidenciate the individual influence of each region in the occurrence of these ectoparasites, this variable was decomposed in dummy variables. Thus, the logistic regression model analyzed each region individually avoiding biases that could occur when variable region is considered without discriminating each of the 20 regions of the State. The region of Bambuí was chosen as a reference for comparison with the other due to the fact that this is the region number one of the database and because it is the closest to the barycenter of the State of Minas Gerais. Also,
Bambuí has systems that have characteristics that make them adequately representative of the poultry industry in the state.

The regions of Belo Horizonte, Juiz de Fora, Viçosa, Pouso Alegre and Oliveira were considered as area of risk for the occurrence of mites due the $\mathrm{OR}>1$. Passos, Unaí and Uberaba regions had no infestation, leading to their exclusion from the model. Differences in the occurrence of feather mites among regions were also described by Jardim et al. (2012), in a study on the occurrence of quill mites on psittacines in conservation facilities in Brazil, observing a greater chance of occurrence in the State of Espírito Santo as compared to Minas Gerais. The occurrence of variations among regions could be attributed to climatic conditions, which would vary according to geographic location. In Figure 1, is presented a map of the State of Minas Gerais and its regions. The northern warmer and drier climate regions were removed from the logistic model due to absence of mite infestation. In contrast, the southern regions presented greater chances, in reason of a cooler and more humid climate. Hernández et al. (2007) also found influence of climatic conditions on the occurrence of mites, with an increase of the population in the rainy season. Other hypothesis to explain the increased risk of infestations in the south regions is the highest density of poultry farms in these areas, which could increase the chances of mite spreading. Regarding the value of the OR of area around Viçosa (Table 2), just one farm with diversified poultry houses profiles was visited (Figure 1). This farm had only one barn without infestations, which may have influenced partially in the OR value and in the cluster analysis after verification of intra-class correlation.

\section{Conclusions}

The high occurrence of mites of genus Megninia may be relevant for industrial chicken production in Minas Gerais, especially in laying hens, and suggests the need for periodic preventive monitoring. The evaluation of the economic impact of Megninia would be important. However, in order to adequately perform control, knowledge on biology and epidemiology is essential. This study verified that an important risk factor for the occurrence of infestations was the presence of subsistence breedings of chickens at the proximity of chicken houses. The results support the thesis that the role of synanthropic birds and the use of wire mesh fences had no significance on Megninia occurrence. Mineral oil also exerted a significant protective effect and must be further investigated.

Regarding the sample size and design of the study, more studies are needed mainly employing longitudinal designs at the same region. Prospective or retrospective studies may improve relevant information about intensity of infestation, seasonal dynamics and incidence of different species of the Megninia genus.

\section{Acknowledgements}

The authors are grateful to Instituto Mineiro de Agropecuária (IMA) and farm owners for permission to visit their properties. They also acknowledge CNPq (Conselho Nacional de Desenvolvimento 
Cientifico e Tecnológico), FAPEMIG (Fundaçâo de Amparo à Pesquisa do Estado de Minas Gerais), CAPES (Coordenaçâo de Aperfeiçoamento de Pessoal de Nivel Superior) and Prpq/UFMG (Pro-reitoria de Pesquisa da Universidade Federal de Minas Gerais) for financial support and fellowships.

\section{References}

Amaral V, Santos SM, Furtado MSF, Rebouças MM. Ocorrência das espécies Megninia cubitalis (Mégnin, 1877) e Megninia ginglymura (Mégnin, 1877) (Acarina Analgidae) em Gallus gallus domesticus (L) no Estado do Ceará, Brasil. Biológico 1975; 41(8): 296-300.

Buim RM, Leffer AMC, Del Fava C, Spinosa HS, Bueno RS, Górniak SL. The first report about Allopsoroptoides galli n.g., n.sp (Acari: Analgoidea: Psoroptoididae) infected layer hens: hematological, serum chemistry, and histopathologic findings. Int J Poult Sci 2013; 12(5): 261-263. http:// dx.doi.org/10.3923/ijps.2013.261.263.

Cunha LM. Aspectos epidemiológicos relacionados à ocorrência de ácaros hematófagos em granjas comerciais de postura no Estado de Minas Gerais e avaliação de armadilhas para captura de Dermanyssus gallinae (ACARI: $D E R M A N Y S S I D A E)$ (DE GEER, 1778). Belo Horizonte: Universidade Federal de Minas Gerais; 2013.

Dohoo I, Martin W, Stryhn H. Veterinary epidemiologic research. Charlottetown: Atlantic Veterinary College; 2003.

Garcia QS, Jacobi CM, Ribeiro BA. Resposta germinativa de duas espécies de Vellozia (Velloziaceae) dos campos rupestres de Minas Gerais, Brasil. Acta Bot Bras 2007; 21(2): 451-456. http://dx.doi.org/10.1590/S010233062007000200018.

Gaud J, Atyeo WT, Barré N. Les Acariens du genre Megninia (Analgidae) parasites de Gallus gallus. Acarologia 1985; 26(2): 171-182.

Guimarães JH, Tucci EC. Evaluation of mineral oil in control of Dermanyssus gallinae (De Geer, 1778) (Acari, Dermanyssidae) in field and laboratory conditions. Rev Bras Entomol 1992; 36(4): 859-862.

Hernández M, González A, Larramendy R, Szczypel B, Ramos M. Ectoparasites diagnosed in laying hens from comercial farms in Cuba. Information of the presence of a new mite from the feathers: Megninia ortari (Acari: Analgidae). Rev Cub Cienc Avic 2006; 30(1): 49-54.

Hernández M, Szczypel B, Larramendy R, Temprana M, Ramos M, Miranda I. Dynamics of the parasitic population: Megninia ginglymura Mégnin (Acari; Analgidae): modelling criteria. Rev Cub Cienc Avic 2007; 31(2): 127-134.
Hosmer DW, Lemeshow S. Assessing the fit of the model. In: Hosmer DW, Lemeshow S, editors. Applied Logistic Regression. 2nd ed. New York: John Wiley \& Sons Inc; 2000. p. 143-202. http://dx.doi. org/10.1002/0471722146.

Jardim CCG, Cunha LM, Rezende LC, Teixeira CM, Martins NRS, Oliveira PR, et al. Quill mites in Brazilian psittacine birds (Aves: Psittaciformes). J Zoo Wildl Med 2012; 43(3): 511-516. http://dx.doi. org/10.1638/2011-0232R1.1. PMid:23082514

Krantz GW. Collection, rearing, and preparation for study. In: Krantz GW, editor. A Manual of Acarology. 2nd ed. Corvallis: OSU Bookstores; 1978. p. 77-98.

Landis JR, Koch GG. The measurement of observer agreement for categorical data. Biometrics 1977; 33(1): 159-174. http://dx.doi. org/10.2307/2529310. PMid:843571

Maurer V, Perler E, Heckendorn F. In vitro efficacies of oils, silicas and plant preparations against the poultry red mite Dermanyssus gallinae. Exp Appl Acarol 2009; 48(1-2): 31-41. http://dx.doi.org/10.1007/s10493009-9254-2. PMid:19229641

Mironov SV. Allopsoroptoides galli n. g., n. sp., a new genus and species of feather mites (Acari: Analgoidea: Psoroptoididae) causing mange in commercially raised domestic chicken in Brazil. Syst Parasitol 2013; 85(3): 201-212. http://dx.doi.org/10.1007/s11230-013-9422-y. PMid:23793494

Mumcuoglu KY, Lutsky IA. Prevalence survey of poultry house mites in Israel. Acarologia 1990; 31(1): 51-56.

Proctor HC. Feather mites (Acari: Astigmata): ecology, behavior, and evolution. Annu Rev Entomol 2003; 48(1): 185-209. http://dx.doi. org/10.1146/annurev.ento.48.091801.112725. PMid:12208818

Reis J. Alguns parasitas de Gallus gallus (L.) verificados em São Paulo. Arq Inst Biol 1939; 10: 147-153.

Rezende LC, Cunha LM, Teixeira CM, Oliveira PR, Martins NRS. Mites affecting hen egg production: some considerations for Brazilian farms. Cienc Rural2013; 43(7): 1230-1237. http://dx.doi.org/10.1590/ S0103-84782013005000088

Tucci EC, Guastali EAL, Rebouças MM, Mendes MC, Gama NMSQ. Infestação por Megninia spp. em criação industrial de aves produtoras de ovos para consumo. Arq Inst Biol 2005; 72(1): 121-124.

Tucci EC, Soares NM, Faccini JLH, Vilas Boas D. Additional information about a mange outbreak by Allopsoroptoides galli (Acari: Psoroptoididae) in commercial laying hens in the state of São Paulo, Brazil. Pesqui Vet Bras 2014; 34(8): 760-762. http://dx.doi.org/10.1590/S0100736X2014000800009. 